\title{
Actor-Network Theory and Stakeholder Collaboration: The Case of Slovenia
}

\author{
Ph.D. Candidate, Lea-Marija Colarič-Jakše, M. Sc
}

\author{
Faculty of organizational studies, Novo mesto
} colaric-jakse@siol.net

\section{Associate Professor, Milan Ambrož}

Faculty of organizational studies, Novo mesto ambrozmilan7@gmail.com

\author{
Doi:10.5901/mjss.2015.v6n3s2p231
}

\begin{abstract}
This paper aims to reveal the impact of collaborative networking on the tourist satisfaction with integral tourism products. We used exploratory factor analysis and general regression model to test the effects of collaboration between stakeholders on Slovenian tourist destination on the satisfaction of tourists with the integral tourist products. Despite intensive research in this field, there is still a gap in the knowledge about the collaboration between local, regional and national stakeholders in the process of creating integral products. This paper contributes to the debate by investigating the collaborative behavior patterns of stakeholders during the conceptualization of the large project on the planning of comprehensive tourism products. The research shows that collaborative networking, competencies, and leadership facilitate the satisfaction of tourists with comprehensive tourist product on the destination Slovenia. Paper offers the applications for steering committees, marketers and consortia coordinators.
\end{abstract}

Keywords: actor-network theory, collaboration, networking, leadership, competencies, integral products

\section{Introduction}

Tourism has the most growing potential of all industries in the world and is always changing. New generations of tourists have new desires, expectations, and goals. Further, modern tourists anticipate innovative and diverse products and services. As a result, the changing of the tourism product landscape demands new approaches to market and marketing (Richards and Wilson, 2008:7). Emerging trends of de-differentiation of tourism goods and services in tourism cover greater range of tourism resources as ever before. New trends include all the goods, even the ones that originally are not tourism products like lifestyle of the tourists and atmosphere on the tourist destination. Increasing heterogeneity of tourism products installs service sectors at the core of the developing process of the making of integral tourism products. Innovation becomes the crucial factor of the firm's company competitiveness (Carvalho and Costa, 2001).

Stakeholder collaboration is a widely recognized as a principal approach to investigate the collaboration processes on the local level of tourism networking (Jamal and Getz, 1995). Number of studies elaborated tourism networking empirically and theoretically in the field of tourism planning (Arnaboldi and Spiller, 2011; Ambrož, 2006; Ambrož and Veljković, 2012).

Sautter and Leisen (1999) investigated the collaboration between the main players in sustainable tourism development. Their findings show that authorities proactively direct and consider the transaction against relationship orientations of key stakeholders. According to Byrd (2007), sustainable tourism development is possible when distinct groups like present visitors, future visitors, present host community, and future host community play stakeholder role in the process of development. Andereck and Vogt (2000:27) and Choi and Sirakaya, 2005) argue that without collective effort it is very difficult to develop a sustainable approach to tourism. De Araujo and Bramwell (1999) research show similar results. They argue that varied stakeholders participated in the planning process, but there was only limited participation by private sectors and NGOs. Garcia-Rosell (2013: 56) research shows that stakeholders that are independent and isolated market actors with clearly defined tasks and roles within the market context, which have more participative practices produce better results.

However, these contributions disregard the contents of the organizing process of collaboration of the stakeholders in integral tourism product planning. This lack of the thorough research on the micro-level of collaboration coordination 
calls for further empirical investigations to support the principles of building and managing partnerships in the tourism system.

The present work seeks to fill this gap by empirically investigating the micro-level collaboration of stakeholders in the Slovenian tourism destination. In this paper, we will develop leadership - network perspective on tourism innovation practices that lead to the construction of the integral tourism products. More precisely, the paper focuses on the selfgenerating process of collaboration in a form of tourism marketing consortia (Fyall and Garrod, 2005:265). We will introduce an innovative organization perspective, which firstly rests on the satisfaction of tourists with integral products and services. Secondly, we will investigate how tourism stakeholders can develop innovative organization from the collaboration process developing of comprehensive tourism products and establishing the informal consortium structures. Further, we will argue that innovation in tourism means developing such kind of innovative organizing practices that allow for the realization of innovative practices through the integration of products and services and collaborating structures.

\section{Literature Review}

Innovation of products and services is a typical organizational pattern of modern and competitive organizations. Tourism actors and agencies develop innovative approaches in the process of making new tourism products for decades. Besides, tourism researchers show constant interest in the innovation of tangible tourism products.

Recently, researchers shifted their attention to other sectors (Carvalho and Costa, 2001; Hjalager, 2202; Carvalho, 2008, and Miles 2005). According to Duim (2008:13) innovation in tourism means developing the ability to make tourismscapes work differently in an innovative way. He argues that actors can foster changes if they reconfigure the collective of actors. Actors have to change the structure of the group in that way that they add new people and new things and integrate them in new products. Asheim and Isaksen (2003) emphasize that participating in clusters and networks provides new potential for innovations and strengthens competitive advantage of organizations and tourism stakeholders. It is important to note in this context that the structure of the tourism industry influences innovation performance (Cano, 2008).

\subsection{Innovative potential of tourism products}

Researchers saw the structure of the organization and the management of the organization as fundamental factors to enhance innovation activity on the organizational level (Jensen et al.. 2007). Leadership has a significant role in this process attempting to increase linkages to other sectors. Besides, leadership promotes the exploitation of innovative potential in the tourism industry parallel to the promotion of authenticity of tourism products (Haven-Tang and Jones, 2012).

According to Johannesson (2005), Actor-network theory (ANT) is a very appropriate tool to explain the collaborative patterns of tourism stakeholders. ANT is a concept of translation that highlights the network practices of different actors. Besides, ANT grasps multiple relational orderings and can draw diverse forms of tourism spatially into analysis. Actor-Network Theory enables a radical new way of describing the travel by critically investigating its ontological conditions (Duim et al., 2013).

Duim (2008: 11) argues that from the actor-network perspective, every innovation involves the reconfiguration of the group of actor in a tourism destination. The changes can occur through the building of transformative ties and through the collaboration of tourism stakeholders in the process of developing of integral tourism products. Latour (2005) argues that not every situation for example making the innovative comprehensive tourism products predetermines some action. Arnaboldi and Spiller (2011) emphasize the coupling of human and non-human form and participate in networks where they can make and innovate integral tourism products.

We can find many works of tourism literature that emphasize the importance of the network approach to the integration of tourism chains (d'Angella \& Go, 2009). Dimanche et al. (2010) show how we can reconfigure the existing resources to create unique and innovative products.

Beaumont and Dredge (2010) show how different approaches to tourism governance on a local level contribute to the active collaboration of tourism stakeholders. The collaborative cultures based on constructive communication in the community that actively engages in a networking process lead to convergence, independence and empowerment of the shared interests. Van der Duim (2007) implies that innovation is a kind of translation or change. We can assume change as a rational and predictable achievement. Or we can see it differently as a flow or process in the form of reading. Reading enables flow of ideas, seeking of allies and support of the stakeholder that make innovation happen. Reading follows to translation that works upon three rules: (1) enrolling stakeholders with leadership actions; (2) building 
competencies; (3) and circulating collaborative networking. Thapa (2011) explored in his research how a social activist initiates changes to facilitate projects in the field of healthcare. He found out that passing on information is critical in sharing information especially when information enters an extensive network. Paget et al. (2010) for example examined the innovations of a tourism company in the particular con- text of French ski resorts. His research findings show that leader translator helped the company to manage interests and enrolled actors to its projects. ANT is a practical concept that follows the Foucault (1970) notion of society and social relations. Foucault's (1970) points out that people construct social relations through practice.

\subsection{Satisfaction of tourism customers}

According to Güler and Crowther (2012), the overall level of tourist satisfaction depends on the total standard of the tourist destination product. The role of accommodation providers on the tourist destination is to understand motivators and expectations of their target audiences (Williams and Uysal, 2004). It is not new that tourism stakeholders continuously try to integrate places, people, and things, build the coherent actor-network, and try to maintain its stability (van der Duim, 2008: 15). This integration results in customer satisfaction, which has the central role in tourism service and marketing literature. Satisfaction of tourists is vital for the tourist destination. It is the tool for measurement of their expectations comparing to the service performance. Collaborative practices of tourism stakeholders depend on the tourist satisfaction. Tourists measure their satisfaction emotionally and link it to the fulfillment of their needs and expectations and the quality of integral tourism products (Jankovic et al., 2011). Comprehensive products are paramount because they satisfy the vast range of the wishes and needs of tourists that visit a particular destination. For example Koutoulas (2004) defines comprehensive tourism products as total tourist products that form a bundle of tangible and intangible components. Koutoulas (2004: 4) argues that tourist products need to satisfy the tourist's needs.

\subsection{Networking competences}

Cornellisen (2011) develops the concept where the combinations of the regime of accumulation or the organization and process of production and consumption stabilize the regime of accumulation. Collection becomes stable and guarantees its reproduction. He speaks of the shift from the Fordism mass production of tourism products to the Postfordist that emphasizes small-scale firms offering tailored packages focusing on niche tourism products. Tailoring is only one-step away from the making of integral tourism products (Campos, 2014) where several stakeholders collaborate and continuously innovate new comprehensive products. Networked-core competencies have an important role in tourism development. Denicolai et al. (2010) explore the relationship between the networking approach and tourism firms and development of tourism core-competences. These competencies play a significant role in tourism development and provide a development path for policymaker actions. Tourism is a service and bases for the actions of people that collaborate to make products that satisfy tourists. Nagarjuna and Kallarakal (2014) point out that human capital is the essential means for the development and growth of the tourism sector. Dimmok et al (2003) hold the notion that the tourism works globally, nationally and locally and stakeholders who work in tourism must develop right competencies. They need the knowledge to establish efficient organization, which bases on close collaboration.

\subsection{Collaborative networking}

Postmodern approaches to tourism development emphasize the development of the community rather the development of the tourism industry (Scheyvens, 2002; Ambrož, 2008).

Van der Duim (2008: 14) uses the concept of tourismscapes to build an alternative way of looking at and researching tourism. He bases his construct on the actor-network theory, which considers the actor-networks as collectives that connect all kind of tourism products like transport, people, technologies, places, facilities, tourism resources, and organizations. His concept integrates and relates people and things in tourism time and space. As a consequence of integration new and specific patterns emerge, and a particular effect of ordering takes place. Van der Duim (2008) sees these tourismscapes as networks that materialize through time. It is important to note that these systems are conditional, change and never achieve the state of equilibrium. Arnaboldi and Spiller (2011) integrate tourism and culture on the micro level interactions among stakeholders. Their research shows that the actor-network theory approach conceptualizes by deploying enrolling actors, fact-building and circulating translations. Authors use these rules to define the "conditional path" that activate specific actions and controversies.

Tourism stakeholders collaborate, when they can share common goals leading to the successful marketing of 
tourism products on a tourism destination. The competition on a tourism market is severe, and it is highly unlikely that only one stakeholder can achieve marketing objectives. The forming of a collective structure in the form of consortium is a very acceptable idea (Hastings, 2008: 43). According to Fyall and Garrod (2005: 264) consortium provides an independent way of acting of stakeholders in making of integral tourism products. Further, consortium can foster interdependence of multi-stakeholder collectives, constructive maintaining of differences besides, it directs future vision and mission of stakeholders, and enables joint decision-making. Morrison (1998) sees the consortia as networking opportunity and as economies of scale. According to his belief, stakeholders can share marketing expertise, use distribution networks, education, training, and the use of financial resources.

According to theoretical issues we propose the conceptual framework (Figure 1), and hypotheses, which base on the previous research findings of actor-networking means of collaboration in tourism:

H1: Leadership style has a positive effect on the tourist satisfaction with integral tourism products.

$\mathrm{H} 2$ : Competences of tourism stakeholders generate tourist satisfaction with comprehensive tourism products.

H3: Collaborative practices of tourism stakeholders result in the satisfaction of tourists with comprehensive tourism products.

Figure 1: Conceptual framework of collaborative networking

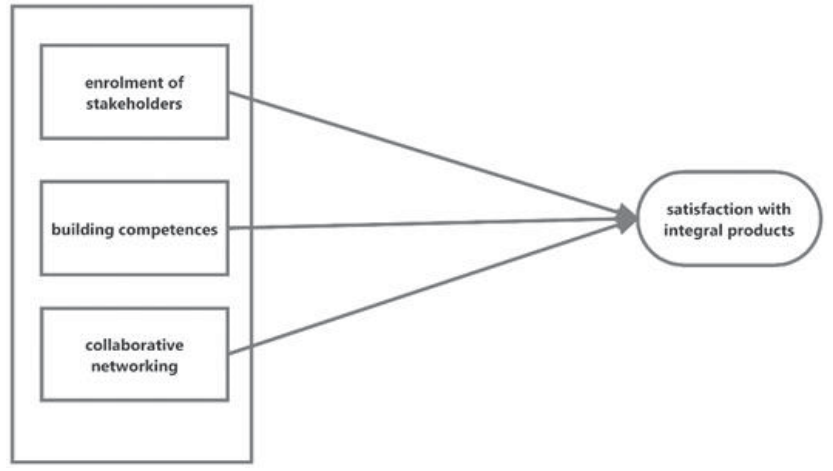

\section{Methodology}

\subsection{Instrument design}

We conducted self-administered questionnaire to test the hypotheses of the conceptual framework. We used the principles of the Actor-network Theory to build the items in the questionnaire. We constructed 19 items to measure leadership, 14 item to measure satisfaction with integral products, 15 items to measure competencies and 11 to measure collaborative networking.

\subsection{Collection of the data}

We distributed the questionnaire with the interval scale from one to five. One on the scale is total negative inclination to the attitude and five means total definite inclination to the attitude to 222 representatives of all level tourism structures and companies in Slovenia. The final sample of respondents consists 222 usable questionnaires with the response rate $100 \%$.

\section{Data Analysis and Results}

The sample in our study consists of $17,12 \%$ individual entrepreneurs, $9,01 \%$ supplement activities leaders, $34,68 \%$ small enterprises managers, 13,69\% middle enterprises managers, 2,25\% large enterprise managers, and 22,95\% micro enterprises.

\subsection{Factor analysis}

We used exploratory factor analysis to reduce data and to find latent factors of the collaboration of the tourism stakeholders in the making and marketing of tourism products. Factor analysis is a statistical tool we can use to reduce a 
set of observable variables to a smaller number of latent factors. According to factor analysis, we can assume that there are a number of potential factors. These factors account for the correlations among observed variables. We present the results of the factor analysis in Table 1. All items that we included in the factor analysis have high commonalities with moderate or high correlations. We included all elements in the factors. Results of the factor analysis support the actornetwork theory and yields four factors. Factor Leadership that accounts for $34 \%$ of total variance, factor Tourist satisfaction that accounts for $12 \%$ of total variance, factor Competences that accounts for $7 \%$ of total variance, and factor Collaborative networking that accounts for $5 \%$ of total variance.

Table 1: Reliability of factors in factors analysis

\begin{tabular}{|c|c|c|}
\hline Framework constructs & Number of items & Standardized Cronbach's Alpha \\
\hline Leadership & 19 & 0,954 \\
\hline Satisfaction of tourists & 14 & 0,957 \\
\hline Competences & 15 & 0,955 \\
\hline Collaborative networking & 11 & 0,865 \\
\hline
\end{tabular}

Cronbach's alpha coefficient shows very high factors reliability. Average correlation among the variables in the factors is very high, from 0,865 to 0,957 .

Table 2: Exploratory factor analysis with Principal components extractions (Varimax Normalized) Loadings are >, 400000

\begin{tabular}{|c|c|c|c|c|}
\hline Variables & 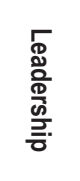 & 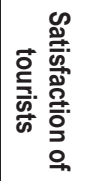 & 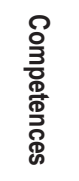 & 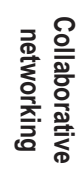 \\
\hline \multicolumn{5}{|l|}{ Leader: } \\
\hline Cooperates efficiently with employees, co-workers, business partners and other stakeholders in complex projects. & 0,670 & 0,180 & 0,342 & $-0,130$ \\
\hline Self-critically estimates his or her actions and the actions of other stakeholders. & 0,672 & 0,154 & 0,213 & $-0,138$ \\
\hline Creates long-term vision of an organization and follows its vision. & 0,733 & 0,204 & 0,238 & $-0,058$ \\
\hline Holds and follows the long-term vision of the organization. & 0,732 & 0,192 & 0,279 & $-0,059$ \\
\hline $\begin{array}{l}\text { Uses different competencies and leadership styles, communicates effectively, holds proper values and integrates } \\
\text { employees and stakeholders on various projects. }\end{array}$ & 0,696 & 0,119 & 0,305 & $-0,000$ \\
\hline Efficiently solves and directs conflicts. & 0,714 & 0,142 & 0,202 & 0,124 \\
\hline Stimulates and directs teamwork. & 0,747 & 0,221 & 0,174 & 0,000 \\
\hline Listens actively. & 0,741 & 0,208 & 0,103 & 0,047 \\
\hline Persuades others to follow his or her vision. & 0,730 & 0,149 & 0,102 & 0,085 \\
\hline Efficiently operates in a multi-cultural environment. & 0,747 & 0,230 & 0,186 & 0,159 \\
\hline Acts innovatively and stimulates others to act innovatively. & 0,684 & 0,071 & 0,269 & 0,186 \\
\hline He or she is always learning. & 0,691 & 0,045 & 0,148 & 0,049 \\
\hline He or she is a marvelous speaker. & 0,593 & 0,082 & 0,230 & 0,204 \\
\hline Efficiently solves complex problems. & 0,780 & 0,080 & 0,179 & 0,036 \\
\hline Cogitates in abstract terms and creates the concepts of future actions of the organization. & 0,682 & 0,098 & 0,236 & 0,050 \\
\hline He or she is capable of using information in various circumstances. & 0,746 & 0,127 & 0,331 & 0,108 \\
\hline He or she is skillful in communication with others. & 0,671 & 0,037 & 0,222 & 0,170 \\
\hline Behaves in an economy way. & 0,648 & 0,051 & 0,189 & 0,191 \\
\hline He or she communicates in different languages. & 0,515 & $-0,064$ & 0,286 & 0,147 \\
\hline Fosters faithfulness of a tourist. & 0,208 & 0,703 & 0,082 & 0,072 \\
\hline Works to provide more tourists on destination. & 0,196 & 0,769 & 0,127 & 0,080 \\
\hline A number of tourists regularly increases. & 0,092 & 0,673 & 0,245 & 0,145 \\
\hline Stimulates better recognition of tourist destination. & 0,118 & 0,709 & 0,226 & 0,163 \\
\hline Destination praise and recognition of tourists. & 0,138 & 0,759 & 0,226 & 0,151 \\
\hline Is enthusiastic about the integral offer of tourism products on a destination. & 0,181 & 0,754 & 0,172 & 0,172 \\
\hline Is enthusiastic about accessibility and wholeness of tourism products offer. & 0,100 & 0,767 & 0,160 & 0,219 \\
\hline Is enthusiastic for the making of individualized tourist products. & 0,124 & 0,757 & 0,181 & 0,294 \\
\hline Is enthusiastic about the authenticity of integral tourism products. & 0,136 & 0,801 & 0,114 & 0,290 \\
\hline Is enthusiastic about the aligning of the tourism products to the lifestyle of a tourist. & 0,155 & 0,720 & 0,177 & 0,308 \\
\hline Is enthusiastic about the choice to select alternative tourism products within the integral tourism products offer. & 0,117 & 0,825 & 0,076 & 0,233 \\
\hline $\begin{array}{l}\text { Is enthusiastic about the possibility to use integral information system that enables the usage of comprehensive tourism } \\
\text { products. }\end{array}$ & 0,141 & 0,723 & 0,039 & 0,264 \\
\hline Is enthusiastic about the awareness consumerism: authentic products, live experience, learning and cultural heritage. & 0,063 & 0,764 & 0,147 & 0,250 \\
\hline
\end{tabular}




\begin{tabular}{|c|c|c|c|c|}
\hline Is enthusiastic for the quality and excellence of the tourism offer. & 0,144 & 0,755 & 0,112 & 0,226 \\
\hline Has competencies for efficient networking in tourism. & 0,249 & 0,085 & 0,732 & 0,129 \\
\hline Has competencies for solving financial problems of tourism development. & 0,200 & 0,132 & 0,695 & 0,043 \\
\hline Has competencies for planning of tourism projects. & 0,274 & 0,154 & 0,701 & 0,063 \\
\hline Has competencies for the scenario planning in the field of tourism. & 0,256 & 0,102 & 0,763 & 0,045 \\
\hline Has competencies for the recognition of the needs and wishes of consumers of tourist products. & 0,148 & 0,135 & 0,747 & 0,052 \\
\hline Research competencies for the studies in the field of tourism. & 0,160 & 0,114 & 0,748 & 0,191 \\
\hline Has competencies for the development of the tailor-made tourism products. & 0,240 & 0,152 & 0,765 & 0,062 \\
\hline Has competencies for the usage of good practices in tourism development. & 0,256 & 0,174 & 0,749 & 0,113 \\
\hline Has competencies for the development of the development of the sustainable oriented organizational culture. & 0,294 & 0,109 & 0,701 & 0,063 \\
\hline Has competencies for the development of the development of the trademark tourism products. & 0,300 & 0,127 & 0,694 & 0,046 \\
\hline Has competencies for the development of the employee - friendly organization. & 0,293 & 0,107 & 0,696 & 0,115 \\
\hline Has competencies for the usage of information technology in production of the virtual tourism products. & 0,293 & 0,218 & 0,716 & 0,141 \\
\hline Has competencies for the making of integral tourism products. & 0,223 & 0,233 & 0,774 & 0,056 \\
\hline Has competencies for the education and training of the tourism actors. & 0,233 & 0,105 & 0,669 & 0,012 \\
\hline Has competencies for the innovative agency in the field of tourism. & 0,249 & 0,215 & 0,742 & 0,032 \\
\hline All stakeholder share shared vision about the creating and innovation of integral tourism products. & 0,194 & 0,243 & 0,037 & 0,680 \\
\hline Stakeholder manage the projects of creation and making of integral tourism products flexible and adaptable. & 0,037 & 0,186 & 0,013 & 0,648 \\
\hline Stakeholders use new ways of organizing patterns in the process of creation and making of integral tourism products. & 0,224 & 0,210 & $-0,023$ & 0,626 \\
\hline Stakeholders efficiently collaborate in the process of creation and making of integral tourism products. & 0,112 & 0,251 & 0,063 & 0,694 \\
\hline Stakeholders share resources and information. & 0,019 & 0,196 & $-0,018$ & 0,613 \\
\hline Stakeholders link transformative across organizations in the process of innovation of integral tourism products. & 0,135 & 0,091 & 0,093 & 0,580 \\
\hline Stakeholders link transformatively in the virtual environment in the process of innovation of integral tourism products. & 0,045 & 0,174 & 0,168 & 0,609 \\
\hline Stakeholders work autonomously in the projects of creation and innovation for integral tourism products. & 0,037 & 0,240 & 0,093 & 0,593 \\
\hline $\begin{array}{l}\text { Stakeholders in tourism organizations work in several tourism agencies and enterprises in innovative processes of } \\
\text { making integral tourism products. }\end{array}$ & 0,141 & 0,244 & 0,149 & 0,526 \\
\hline $\begin{array}{l}\text { Stakeholders in tourism organizations continuously enter and re-enter in the networks when creating innovating and } \\
\text { marketing new integral tourism products. }\end{array}$ & $-0,114$ & 0,182 & 0,139 & 0,505 \\
\hline $\begin{array}{l}\text { Stakeholders in tourism organizations collaborate on the equal basis and independently of the status of the innovative } \\
\text { networks. }\end{array}$ & $-0,063$ & 0,072 & 0,039 & 0,622 \\
\hline
\end{tabular}

\subsection{Regression analysis}

We now proceed with the analysis of how the factors we included in the conceptual framework present Actor-Network Theory. We tested the proposed actor-network model with three factors. We regressed the predictors Collaborative networking, Competences and Leadership on Satisfaction of tourists with integral tourism products. We forecasted that enrolling stakeholders with leadership actions, building competencies and circulating collaborative networking, would produce satisfaction of the tourists with comprehensive tourism products. Results from the General Regression Model are in Table 3.

The $\mathrm{R}^{2}$ statistics indicates that the model explains $62,5 \%$ of the variability in Tourist satisfaction. The adjusted Rsquared statistic, which is more suitable for comparing models with different numbers of independent variables, is $38,3 \%$. The model shows statistically significant results $(F=46,671 ; p=0,0000)$.

Table 3: Overall fit of the regression model

\begin{tabular}{|c|c|}
\hline Overall fit of the model for Tourist satisfaction & Parameters \\
\hline Multiple R & 0,625 \\
\hline Multiple $\mathrm{R}^{2}$ & 0,391 \\
\hline Multiple R $\mathrm{R}^{2}$ adjusted & 0,383 \\
\hline $\mathrm{F}$ & 46,671 \\
\hline $\mathrm{p}$ & 0,0000 \\
\hline
\end{tabular}

We further discuss the result with the factors of the actor-network theory, starting with the estimates of the regression model. The results show that all factors have a significant effect on the likelihood of tourists' satisfaction with integral tourism products. Three factors have highly significant effects. 
Table 4: Parameter estimates for Tourist satisfaction - Sigma restricted parameterization

\begin{tabular}{|c|c|c|c|c|c|c|}
\hline Predictors & Parameter & Standard error & $\mathrm{t}$ & $\mathrm{p}$ & Beta $(\boldsymbol{B})$ & Standard error of $\beta$ \\
\hline Leadership & 0,219 & 0,094 & 2,337 & 0,020 & 0,152 & 0,065 \\
\hline Competences & 0,235 & 0,074 & 3,199 & 0,002 & 0,210 & 0,066 \\
\hline Collaborative networking & 0,537 & 0,067 & 8,018 & 0,000 & 0,445 & 0,056 \\
\hline
\end{tabular}

The strongest and highly significant effect has the factor Collaborative networking ( $\beta=0,445 ; p=0,000$ ). Competences $(B=0,210 ; p=0,002)$ and Leadership ( $B=0,152 ; p=0,020)$ also have clear, significant, but moderate to weak effects. These results are in line with our hypotheses and we can accept $\mathrm{H} 1, \mathrm{H} 2$, and $\mathrm{H} 3$ respectively.

According to the issues relevant to collaborative interaction of tourism stakeholders, we defined initial conceptual framework to conduct the research. We draw on the concept of the Actor-Network Theory (van der Duim, 2008; Arnaboldi and Spiller, 2011),. We isolated three principles that direct our conceptual framework: leadership in enrolling the stakeholders, competencies to building facts, and the collaborative networking as a form of circulating translations. Initial framework shows no predetermination in developing the principles of collaboration to make integral tourism products. We presumed that all stakeholder want to participate in this process freely and autonomously.

First, results of the regression analysis support our hypothesis about the collaborative practices of tourism stakeholders lead to the satisfaction of tourists with integral tourism products. Tourists will more likely show satisfaction with comprehensive tourism products when tourism stakeholders efficiently collaborate in the making and marketing of such products. It seems that variables summoned in the factor about collaborative interaction between stakeholders captured the positive consequences of such kind of collaboration. Our results show that collaborative networking keeps the interested parties in the project. Complex projects of making of integral tourism products are complex, and the commitment of all interested parties in the project is a difficult task. Collaborative networking is efficient in certain conditions. The trust and willingness to collaborate in the innovation process is most essential prerequisite. Stakeholders must share the shared vision, and they have to adapt and be flexible in the implementation of the project. If they use innovative patterns of organizing, collaborate on an equal basis and work independently, their contribution is valuable.

Second, tourists will more likely show the satisfaction with integral tourism products when they feel they have the right competencies. Further, they must feel that they have innovative potential to make comprehensive tourism products. Good practices can help them to realize the goals of the project. It is crucial that they have the right information about the needs and wishes of the tourists about the nature of the integral tourism products. Stakeholders must have the vision and knowledge to innovate comprehensive products, to plan innovations and to avoid generation of unrealistic expectations about the financial gains.

Third, leadership as an outset of the conceptualisation is the weakest factor in our conceptual framework. Enrolling actors in our research through solving complex problems and stimulating and directing teamwork is the strongest link, especially when we consider different cultural lenses of collaboration. It seems that stakeholders in our research know how to use information about integral products in various circumstances. Additionally, our respondents think that the leader should create, maintain, and implement the long-term vision of establishing the comprehensive tourism products. His contribution is valuable in stimulating innovation, leading the stakeholders and communicating the vision.

\section{Conclusions}

The conceptual framework in this paper offers a novel perspective on the leadership of integral tourist products projects. Our research shows rather rigid sequential definition of steps because of the quantitative research method. We suggest that qualitative analysis would reveal more precise conditional path of innovating and marketing of integral tourism products. The results reveal that the initial phase of the project is rather weak. Enrolling of the stakeholders in the innovative process is not elaborated enough. These findings aim at future research that should confirm the actor-network approach in our study.

According to the literature and research projects, stakeholder collaboration is a difficult and complex task. Innovation in the form of integral tourism products is a complex and challenging task. Such a project involves many obstacles. It is crucial to note that the involvement of the stakeholders is paramount. It is the most important initial project step. The motivation, the selection and enrolment of stakeholders is crucial for the success of the project. Only stakeholders that collaborate can legitimate the project and use their innovative potential.

Innovation is always a difficult task. The willingness of the stakeholders to participate in such project is the first, and very important success factor. Even more important is to translate the innovative ideas to action and to establish the 
link between the presentation and performance.

Involving stakeholders has another important effect. According to the results of our study, the stakeholders have a strong sense of collaborating. It is crucial that they have an opportunity to participate in several projects.

We conclude that results in the form of a network is useful for the planning of tourism development and the development of tourism destination. People who coordinate steering committees or consortia could find this model useful to plan complex actions to enroll and engage stakeholders in the process of planning, creating and marketing of integral tourism products.

\section{References}

Ambrož, M. (2006). "A third way" of tourism planning: case of Slovenia. V: Ovsenik Rok (ed.), KIERETA, Iwona (Eds.). Destination management. Frankfurt is Main [etc.]: P. Lang, pp. 26-44.

Ambrož, M., Veljković, B. (2012). Effects of local governance on the sustainable local community development. In: KRSTIĆ, Bojan (Ur.). Improving the competitiveness of the public and private sector by networking competencies: [thematic collection of papers of international significance]. Niš: Faculty of Economics, pp.53-72, table.

Arnaboldi, M., Spiller, N. (2011). Actor-network theory and stakeholder collaboration: The case of Cultural Districts. Tourism Management 32, pp. 641-654.

Asheim, B. T. and Isaksen, A. (2003). SMEs and the regional dimension of innovation. In: Asheim, B. T. et al. (Eds.), Regional innovation policy for small-medium enterprises. Edward Elgar, Cheltenham, UK, Northampton, USA, pp. 21-46.

Beaumont, N., Dredge, D. (2010). Local Tourism governance: A comparison of three-network approaches. This is an electronic version of an article published in Journal of Sustainable Tourism Vol. 18, Iss. 1, January 2010, 7-28. Journal of Sustainable Tourism is available online at: http://www.informaworld.com/smpp/title $\sim d b=j o u r ~ c o n t e n t=t 794297833$.

Campos, M. J.Z. (2014). Partnerships, Tourism and Community impact. In: »The Wiley-Blackwell Companion to Tourism. Ed. \& Alan A. Lew; C. Michael Hall; Allan M. Williams. Chichester, John Wiley \& Sons, chapter 45, pp. 567-577.

Cano, X. P. (2008). Innovation typology in tourism. Master thesis, Universidad de Girona,

Carvalho, L., Costa, T. (2011). Tourism innovation - a literature review complemented by case study research. International conference on tourism \& Management Studies. Algarve, Book of Proceedings, Vol. 1, pp. 26-33.

Carvalho, L. (2008). Innovation in Entrepreneurship: A model for service sector, Ph.D. Thesis, Evora University, Portugal.

Choi, H.C. and Sirakaya, E. (2006). Sustainability indicators for managing community tourism. Tourism Management, 27, pp. $1274-$ 1289.

d'Angella, F., \& Go, F. M. (2009). Tale of two cities' collaborative tourism marketing: Towards a theory of destination stakeholder assessment. Tourism Management, Vol. 30, Iss.3, pp. 429-440.

De Arujo, L. M., Bramwell, B. (1999). Stakeholder Assessment and Collaborative Tourism Planning: The Case of Brazil's Costa Dorado Project. Journal of sustainable tourism, Vol. 7, Iss. 3\&4, pp. 365-378.

Denicolai, S., Cioccarelli, G., Zucchella, A. (2010). Resource-based local development and networked core competencies for tourism excellence Tourism Management, Vol. 31, Iss. 2, pp. 260-266.

Dimanche, F., Paget, E., Mounet, J. P. A tourism innovation case: An Actor-network approach. Annals of Tourism Research, Vol.37, Iss. 3, pp. 828-847.

Dimmock, K., Breen, H., Walo, M. (2003). Management Competencies: An Australian Assessment of Tourism and Hospitality Students. Journal of the Australian and New Zealand Academy of Management, Vol. 9, Iss. 1.

Erick T. Byrd, (2007) "Stakeholders in sustainable tourism development and their roles: applying stakeholder theory to sustainable tourism development", Tourism Review, Vol. 62, No. 2, pp.6-13.

Foucault, M. (1970). The Order of Things: An Archaeology of the Human Sciences. New York, Random House, Inc.

Fyall, A., Garrod, B. (2005). Aspects of tourism. Tourism marketing: A collaborative approach. Tonawanda, Channel View Publication.

Garcia-Rosell, J. C. (2013). A Multi-stakeholder perspective on sustainable marketing: Promoting sustainability through action and research. Rovaniemi, Lapland University Press.

Güler, A., Crowther, D. (2012). Business Strategy and Sustainability. UK, Howard House, Emerald Group Publishing Limited.

Hastings, E. (2008). Tourism partnerships as a method for increasing destination creativity and competitiveness. In: Richards, G., Wilson, J. (Eds.) from cultural tourism to creative tourism, Part 2: Changing structures of collaboration. Proceedings of the ATLAS international conference Barcelona.

Haven-Tang, C. Jones, E. (2012). Local leadership for rural tourism development: A case study of Advent, Monmouthshire, UK. Tourism Management Perspectives, Vol. 4: pp. 28-35.

Hjalager, A. M. (2002). Repairing innovation defectiveness in tourism. Tourism Management, Vol. 23, pp. 465-474.

Jamal, B. T., \& Getz, D. (1995). Collaboration theory and community tourism planning. Annals of Tourism Research, 22(1), 186-204.

Janković, S., Vejzagić, V., Vlašić, D. (2011). International Business \& Economics Research Journal, Vol. 10, Iss.1, pp. 63-72.

Jensen, M.B., et al. (2007). Forms of knowledge and modes of innovation. Research Policy, Vol. 36, pp. 680-693.

Johannesson, G. T. (2005). Tourism translations: Actor-Network Theory and tourism research. Tourist Studies, Vol.5, Iss. 2, pp. 133150.

Koutoulas, D. (2004). Understanding the tourism product. Interim symposium of the research committee on international tourism (RC 50) 
of the International Sociological Association (ISA) on the topic, Understanding tourism - theoretical advances, Mytilini, Greece, University of Aegean.

Latour, B. (2005). Reassembling the social: An introduction to Actor-Network-theory. Oxford: Clarendon.

Miles, I. (2005), Innovation in services, in Fagerberg, J., et al..; (Eds.) the Oxford handbook of innovation. Oxford, Oxford University Press, pp. 433-458.

Morrison, A. (1998). Small firm co-operative marketing in a peripheral tourism region. International Journal of Contemporary Hospitality Management, Vol. 19, No. 5, pp. 191-197.

Nagarjuna, G., Kallarakal, T. K. (2014). Expectations of Tourism Industry on Competencies and Tourism Education. International Journal of Advanced Research, Vol. 2 Iss. 1, pp. 738-745.

Paget, E., Dimanche, F. \& Mounet, J. (2010). A tourism innovation case: An Actor-Network approach. Annals of Tourism Research: A Social Sciences Journal, Vol. 37, Iss. 3, pp. 828-847.

Sautter, E. T., Leisen, B. (1999). Managing stakeholders a tourism-planning model. Annals of tourism research Vol. 26, No. 2, pp. 321328.

Sautter, E. T. and Leisen, B. (1999). Managing stakeholders: A tourism-planning model. Annals of Tourism Research, Vol. 26, Iss. 2, pp. $312-328$.

Thapa, D. (2011). The role of it actors and networks in development: the case study of a wireless project in Nepal. The Electronic Journal on Information Systems in Developing Countries, Vol. 49, Iss. 1, pp. 1-16.

Van der Duim, R., Johannesson, Ren, C., G. T. (2013). Ordering, materiality, and multiplicity: Enacting Actor-Network Theory in tourism. Tourist studies,

Williams, J. A., Uysal, M. (2004). Current issues and development in hospitality and tourism satisfaction. Journal of Quality Assurance in Hospitality \& Tourism, Vol. 4, Iss. 3/4, pp. 60-72. 